Landolt-Börnstein Physikalisch-chemische Tabellen Fünfte, umgearbeitete und vermehrte Auflage. Herausgegeben von Prof. Dr. W. A. Roth und Prof. Dr. K. Scheel. Ergänzungsband 3, Teil 1. Pp. viii + 734. 108 gold marks. Teil 2. Pp. viii +735-1814. 162 gold marks. (Berlin : Julius Springer, 1935.)

THE third supplement of the familiar "LandoltBörnstein-Roth" tables is divided into three parts since a very large amount of new matter has to be dealt with. The two volumes under review are Parts I and II; Part III, dealing with electrical, magnetic and thermal properties, is to appear during this year.

A glance at the contents reveals some of the directions in which active research has been prosecuted during the last few years. Part 1 contains large additions to the tables of dipole moments, and records a considerable amount of new work on the com. pressibilities of liquids and gases. A new table of the occurrence and relative abundance of isotopes is appropriately introduced, since nearly all the elements have now been analysed. Another new table which indicates the trend of modern work records the nuclear distances and vibration frequencies of simple molecules deduced from infra-red and Raman spectra.

Part 2 contains a large amount of new spectroscopic data, including a useful table of series and terms in line spectra. The Raman effect, which was first tabulated in the second supplement of these tables, occupies 280 pages in the third supplement. New tables in Part 2 include those dealing with hyperfine structure of spectral lines, with band spectra, and with the absorption of light in the infra-red.

There is no need to stress the immense value of the Landolt-Börnstein-Roth tables and their supplements. Physicists and physical chemists owe a debt of gratitude to the present editors, Profs. Roth and Scheel, which is increased by each new volume that is published.

S. S.

\section{L'Ethnie française}

Par Prof. Dr. George Montandon. (Bibliothèque scientifique.) Pp. $240+48$ plates. (Paris : Payot et Cie., 1935.) 30 francs.

Prof. Montandon opens his study of the racial characters of the population of France dramatically with the statement that there is no French race-a statement presumably pour épater le bourgeois, as it is one with which the vast majority of his colleagues in anthropology would have no quarrel, and, indeed, would scarcely regard as novel.

After an exposition of the hologenetic point of view in the origin and distribution of races on the lines of his previous works, of which an excellent summary appears in Scientia for September, 1935, Prof. Montandon describes the distribution of racial characters in the French population so far as it has now been observed, and bases thereon a classification of racial types. His classification, as he points out, differs in certain essentials from that of Deniker, which distinguishes six racial types, three of them belonging or closely related to the Alpine group, and three to the Mediterranean. Prof. Montandon distinguishes four main types with sub-types, and three more or less localised groups, the most important innovation on Deniker's classification being the recognition of a Nordic element with its sub-types. The author maintains that it is possible also to distinguish a Basque type, this differentiation being based mainly on the form of the nose. This type was overlooked by Deniker through his reliance on a too limited number of characters as his basis of classification.

Dr. Montandon's study is a welcome reopening of a question which requires reconsideration in the light of modern methods of inquiry and recent theory.

\section{An Introduction to Astronomy}

By Prof. Robert H. Baker. Pp. vi+312. (London : Macmillan and Co., Ltd., 1935.) 12s. 6d. net.

THE author of this book is professor of astronomy in the University of Illinois. In 1930 he wrote "Astronomy", containing five hundred pages and published by the Van Nostrand Company, New York. The new "Introduction to Astronomy" is a shorter, simpler, but more attractive book, which presents the more essential elements of astronomy in a clear way by means of careful writing, skilful diagrams and good photographs. The charm of the book is somewhat disturbed by examination or revision questions at the end of each chapter. For example, on page 282 is a section headed "Interstellar space is not empty"; and seven pages later comes the question "What are the reasons for believing that interstellar space is not empty ?" There are, however, questions requiring some imagination, such as (p. 305) - "Describe the appearance of the heavens as viewed from somewhere in the arms of Andromeda Nebula". The request to "show that Kepler's laws completely disproved the Ptolemaic system" (p. 160) raises some interesting philosophical questions which recall Poincaré.

This book is entirely devoid of any mathematical formulæ or calculations. The publishers are, however, justified in recommending students to "retain it for your reference library. You will use it many times in the future". Students should not burn their books behind them. No doubt as the evil visage of examinations recedes into the background, there will be more pleasure in life, in astronomy and in the book under review.

\section{An Introduction to Cultural Anthropology}

By Prof. Robert H. Lowie. Pp. xiii + 365. (London : George G. Harrap and Co., Ltd., n.d.) 10s. 6d. net.

STUDENTs of anthropology will welcome an English edition of Dr. Lowie's valuable review of the field covered by the study of cultural anthropology, which appeared in the United States in 1934. In collecting illustrative material, good use has been made of the results which have accrued from the intensive ethnographical study of the tribes of California, now in progress for some years, but comprehensively not so widely known by British students as it deserves. 